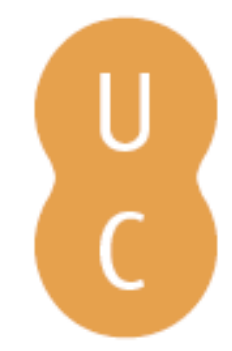

\title{
nommalina
}

\section{O que comem os orixás nos terreiros de candomblé de nação Ketu de Salvador, Bahia: uma perspectiva etnoarqueológica}

Autor(es): $\quad$ Junior, Ademir Ribeiro; Lima, Tania Andrade

Publicado por: Imprensa da Universidade de Coimbra

URL

persistente: URI:http://hdl.handle.net/10316.2/45240

DOI: $\quad$ DOI:https://doi.org/10.14195/978-989-26-1721-3_13

Accessed : $\quad$ 26-Apr-2023 06:31:32

A navegação consulta e descarregamento dos títulos inseridos nas Bibliotecas Digitais UC Digitalis, UC Pombalina e UC Impactum, pressupõem a aceitação plena e sem reservas dos Termos e Condições de Uso destas Bibliotecas Digitais, disponíveis em https://digitalis.uc.pt/pt-pt/termos.

Conforme exposto nos referidos Termos e Condições de Uso, o descarregamento de títulos de acesso restrito requer uma licença válida de autorização devendo o utilizador aceder ao(s) documento(s) a partir de um endereço de IP da instituição detentora da supramencionada licença.

Ao utilizador é apenas permitido o descarregamento para uso pessoal, pelo que o emprego do(s) título(s) descarregado(s) para outro fim, designadamente comercial, carece de autorização do respetivo autor ou editor da obra.

Na medida em que todas as obras da UC Digitalis se encontram protegidas pelo Código do Direito de Autor e Direitos Conexos e demais legislação aplicável, toda a cópia, parcial ou total, deste documento, nos casos em que é legalmente admitida, deverá conter ou fazer-se acompanhar por este aviso. 
Carmen Soares

Gilene da Silva Gomes Ribeiro

(coords.)

\section{Mesas \\ LUSO-BRASILEIRAS}

\section{ALIMENTAÇÃO, SAÚdE \& GULTURA}

\section{VOLUME I}

IMPRENSA DA UNIVERSIDADE DE COIMBRA COIMBRA UNIVERSITY PRESS

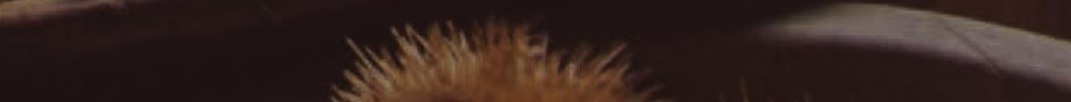




\title{
O QUE COMEM OS ORIXÁS NOS TERREIROS DE candomblé de nação Ketu de Salvador, Bahia: UMA PERSPECTIVA ETNOARQUEOLÓGICA
}

\author{
(What the orishas eat in the Ketu nation candomblé temples \\ of Salvador, Bahia: an ethnoarcheological perspective)
}

\author{
Ademir Ribeiro Junior \\ Instituto do Patrimônio Histórico e Artístico Nacional, \\ Universidade Federal do Rio de Janeiro, Museu Nacional. \\ Doutorando do Programa de Pós-Graduação em Arqueologia \\ (aribeirojunior@gmail.com) \\ Tania Andrade Lima \\ Universidade Federal do Rio de Janeiro, \\ Museu Nacional, Departamento de Antropologia. \\ Pesquisadora do Conselho Nacional de Desenvolvimento \\ Científico e Tecnológico - CNPq \\ Projeto DIAITA: Património Alimentar da Lusofonia \\ (talima8@gmail.com)
}

Resumo: Mais que o simples ato de nutrir-se, podemos entender a alimentação, do ponto de vista da arqueologia, como uma atividade primordial das sociedades humanas, na qual tanto a sua materialidade quanto as suas práticas se revestem de simbolismos e significados, que ao mesmo tempo refletem e transformam os indivíduos e as estruturas sociais. Esse caráter simbólico e ativo da alimentação é visível nas linhagens dos terreiros de candomblé mais antigos da nação Ketu de Salvador e seus descendentes. Esses terreiros são templos religiosos de matriz cultural africana onde são celebrados principalmente os deuses originários do panteão iorubá, da Nigéria e do Benim. A partir de pesquisa bibliográfica, de observações participantes de cerimônias religiosas públicas e privadas e de entrevistas com informantes que detêm o conhecimento tradicional sobre a alimentação nos terreiros de candomblé, pretendemos: a) apresentar sucintamente o levantamento das pesquisas realizadas no Brasil relacionadas à alimentação da população de origem africana escravizada e das comunidades afro-brasileiras; b) relacionar o legado cultural intangível, com a cultura material que lhe dá substância e suporte; c) classificar os diferentes tipos de comidas e analisar os principais pratos destinados aos orixás, sintetizando informações históricas sobre a constituição dos ingredientes usados.

PALAVRAS-CHAVE: alimentação ritual, candomblé, materialidade, arqueologia da Diáspora Africana, etnoarqueologia. 
Aвstract: More than a simple act of nourishment, we can interpret eating from an archaeological point of view, as the primordial activity of human societies in which both its materiality and practices are cloaked with symbolism and meanings, which simultaneously reflect and transform individuals and social structures. The symbolic and active nature of eating is visible in the lineages of the oldest Ketu nation candomblé temples of Salvador and their descendants. These temples are of an African cultural origin, where gods mainly originating from the Yoruba pantheon Nigeria and Benin are celebrated. From a bibliographical research, participant observations of public and private religious ceremonies and interviews with specialists who hold traditional knowledge on eating in candomblé temples, we intend to: a) succinctly present the findings of research performed in Brazil related to the eating habits of the enslaved population; b) relate the intangible cultural legacy to the material culture which provides it with substance and support; c) classify the different types of food and analyze the main dishes intended for the orishas in Ketu nation temples in Bahia, summarizing historical information about the composition of the ingredients used.

KEYWords:ritual food, candomblé, materiality, archaeology of the African Diaspora, ethnoarchaeology.

O objetivo deste trabalho é refletir sobre as pesquisas relacionadas à alimentação nos terreiros de candomblé da Bahia, a partir de uma perspectiva arqueológica, ou seja, que interpreta a cultura material como documento passível de ser analisado através da forma (no caso, os ingredientes, processos de transformação, arranjos ou disposições formais); no espaço (o lugar onde a comida é feita, servida, descartada); e no tempo (mudança diacrônica dos aspectos formais e espaciais). Como veremos adiante, a maioria dos estudos já publicados sobre esse assunto se concentra na natureza dos pratos, abordando os ingredientes e os modos de preparo. $\mathrm{O}$ espaço na esfera da alimentação dos terreiros já foi abordado por alguns estudiosos, mas ainda há lugar para novas pesquisas. Contudo, a relação dos costumes e gostos alimentares com o passar do tempo é o aspecto mais negligenciado, e é aí que pode entrar a contribuição da Arqueologia.

Há uma interpretação, que consideramos ultrapassada, que vê a cultura das comunidades de candomblé de forma essencialista e estática, como se essas comunidades representassem a transposição das culturas africanas para o Brasil, quando na verdade elas são fundamentalmente dinâmicas. Os hábitos alimentares também podem ser historicizados ${ }^{1}$, pois eles mudam ao longo

\footnotetext{
${ }^{1}$ Flandrin e Montanari 1998: 16.
} 
do tempo, mas de uma forma muito mais lenta que os episódios ou ciclos conjunturais históricos ligados a outras esferas da vida humana, pois isso ocorre na "longa duração", extensão de tempo necessária, segundo Braudel, para ocorrer a mudança das estruturas sociais. Além disso, refutamos a visão da cultura como um conjunto de conhecimentos tradicionais passivamente herdados. A cultura, e em especial a cultura material, é entendida como significativamente constituída e usada ativamente, não apenas refletindo aspectos sociais, mas também estruturando a ação social, simultaneamente como produto e vetor de relações sociais ${ }^{2}$. Assim, mais que o simples ato de nutrir, a alimentação pode ser entendida, do ponto de vista da arqueologia, como uma atividade primordial das sociedades humanas, na qual tanto a sua materialidade quanto as suas práticas se revestem de simbolismos e significados, que ao mesmo tempo refletem e transformam os indivíduos e as estruturas sociais. Como disse Mary Douglas, "food is not feed" ${ }^{3}$.

Os terreiros de candomblé são comunidades religiosas formadas em torno de um templo, cujo espaço geralmente inclui: a) um barracão para a dança pública das entidades, os orixás, onde o líder religioso e os integrantes mais importantes possuem cadeiras e locais exclusivos; b) os quartos ou casas dessas divindades, onde são guardadas as formas materiais sacralizadas, chamadas de assentamentos; c) um mato, ou bosque sagrado, ou ainda quintal, onde são cultivadas árvores e ervas usadas ritualmente, além de áreas de moradia familiar e convivência comunitária.

Existe muita diversidade entre os terreiros de candomblé. Eles se autodiferenciam a partir das naçôes, conceito que designa as modalidades rituais originadas na Bahia a partir das tradições culturais étnicas africanas dos fundadores dos terreiros antigos, matrizes dos atuais, mas que ao longo do tempo ficou circunscrito a significados estritamente religiosos, independentemente da ascendência biológica e étnico-cultural dos novos integrantes. Um mapeamento dos terreiros de Salvador cadastrou, em 2009, mais de 1.100 templos em funcionamento. Entre eles havia mais de 40 tipos de nações e combinações de nações diferentes ${ }^{4}$. Segundo esse estudo, os terreiros de nação Ketu perfazem sozinhos cerca de $60 \%$ de todos os terreiros cadastrados. Ketu, reino iorubá situado no que é hoje o Benim, foi a localidade preponderante de origem dos negros escravizados aportados à Bahia no século XIX.

Além de atualmente serem mais numerosos, o prestígio e o reconhecimento dos terreiros antigos da nação Ketu acabaram por estruturar uma espécie de ortodoxia ritual, “o culto jeje-nagô", que influenciou até os terreiros de outras

\footnotetext{
${ }^{2}$ Hodder 1982.

3 Douglas 2011.

4 Teles 2009: 5.
} 
nações e tradições culturais. O terreiro Ilê Axé Iyá Nassô Oká, mais conhecido como Casa Branca, localizado no Engenho Velho da Federação, foi fundado provavelmente entre o final do século XVIII e a primeira metade do século XIX. Esse terreiro foi tombado como patrimônio cultural brasileiro em 1986. É considerado como o mais antigo em funcionamento e como a matriz de todos os outros terreiros de tradição Ketu de Salvador. Apesar de utilizarmos informações já publicadas sobre outros terreiros tradicionais dessa nação, no nosso estudo etnoarqueológico estamos com o foco mais voltado para a sucessão ou linhagem dos terreiros Ketu que se inicia na Casa Branca, de onde saiu Eugênia Anna dos Santos, Mãe Aninha, que fundou o Ilê Axé Opô Afonjá em 1910 (tombado como patrimônio cultural brasileiro em 2000); e de onde saiu o babalorixá Balbino Daniel de Paula, que fundou o Ilê Axé Opô Aganju em 1967 (tombado como patrimônio cultural baiano em 2005); e, finalmente, de onde saiu o babalorixá Jairo José de Oliveira Barros Junior, que fundou o Ilê Axé Opô Oyá Igable em 2007.

A contextualização da cozinha dos cultos afro-brasileiros dentro da história da alimentação pode ser vista na abrangente historiografia escrita por Ulpiano T. Bezerra de Menezes e Henrique Carneiro ${ }^{5}$. A gastronomia baiana e as comidas dos terreiros de candomblé têm despertado o interesse de muitos pesquisadores, desde o final do século XIX. Não queremos dar conta de todos os que se dedicaram a essa temática. A seguir, apenas indicamos as principais referências que usamos para a nossa reflexão. Outras obras de interesse serão apontadas ao longo do texto nos momentos oportunos.

Começando por Raimundo Nina Rodrigues, médico e professor da Escola de Medicina da Bahia, foi um dos pioneiros do estudo sobre o negro no Brasil ao publicar na Revista Brasileira, entre 1896 e 1897, uma série de artigos que seriam reunidos mais tarde no livro $O$ animismo fetichista dos negros baianos, publicado na França, em 1900. Há uma passagem em que ele mostra o significado das oferendas, a partir da descrição das comidas e sacrifícios oferecidos em uma festa de terreiro: "certamente os negros não acreditam que os fetiches comam os alimentos materiais, mas que o recebem sob a forma da alma ou fantasma do alimento" ${ }^{6}$. Em outro livro denominado Os africanos no Brasil (publicação póstuma cujos rascunhos foram escritos entre o fim do século XIX e o ano da sua morte, 1906), há descrições detalhadas sobre as culturas, as línguas, as artes plásticas e a religião dos últimos africanos que viveram na condição de cativos. Entretanto, sobre a alimentação dos negros, dedica apenas um parágrafo no capítulo sobre "as nações pretas que se extinguem”, em que descreve alguns pratos habituais dessas pessoas, os

\footnotetext{
5 Meneses e Carneiro 1997.

6 Rodrigues 2006: 94-95.
} 
quais são hoje muito populares entre a população baiana, como o vatapá, o caruru, o bobó, o mungunzá e o acarajé ${ }^{7}$. Sobre a alimentação nos terreiros, faz apenas algumas citações incidentais a respeito de algumas oferendas para os orixás nas duas obras publicadas.

O interesse por essa temática foi maior em Manuel Querino - artista baiano, intelectual negro e ativista político -, que escreveu, em 1922, um livro dedicado ao ofício das cozinheiras de sua terra, $A$ arte culinária na Babia. Nessa obra, faz um inventário das receitas, ingredientes e modos de fazer da comida "de sal" e "de doce" que eram costumeiros em Salvador e no Recôncavo Baiano no início do século XX. A estrutura da obra separa as comidas que ele chamou de "puramente africanas", feitas com ingredientes e preparos típicos da África e habituais entre os africanos "boçais” com que ele conviveu, daquelas criadas em solo baiano, em que se fundiram ingredientes e modos de fazer europeus e orientais.

A partir dos estudos seminais de Manuel Querino e da lacuna nas pesquisas de Nina Rodrigues sobre os alimentos rituais do candomblé, surgiram outras abordagens sobre essa temática. Mãe Aninha, do Ilê Axé Opô Afonjá, publicou, em 1937, nos apêndices dos Anais do II Congresso Afro-brasileiro, as concisas Notas sobre Comestiveis Africanos, em que lista 25 comidas rituais, seus nomes "africanos" e os ingredientes principais, mas não discorre de forma pormenorizada sobre o modo de fazer e em que ocasiões ou para quais orixás são ofertadas ${ }^{8}$.Édison Carneiro, pesquisador da cultura afro-brasileira e escritor do clássico Candomblés da Babia, publicado em 1948, avançou nessa questão, investigando sistematicamente as comidas preferidas de cada orixá, mesmo que muito sucintamente. Roger Bastide, sociólogo francês que lecionou por cerca de vinte anos no Brasil e produziu diversas obras cujo tema são as comunidades negras, publicou dois artigos na década de 1950 intitulados A cozinha dos deuses (Alimentação e Candomblés) e Cozinha africana e cozinha brasileira, obras que atentam para as mudanças e readaptações culinárias e destacam a importância dada à alimentação ritual nos terreiros de candomblé 9 . No campo da história, Luís da Câmara Cascudo, pesquisador potiguar, publicou, em 1967, a História da alimentação no Brasil, um dos mais abrangentes estudos a partir de pesquisas documentais. Sobre o tema que nos interessa, ele dedicou capítulos sobre as contribuições africanas na culinária brasileira, as comidas dos negros escravizados e os mitos criados em torno da cozinha baiana. Da etnografia e antropologia das religiões afro-brasileiras, destacam-se os trabalhos de Raul Lody, antropólogo carioca que escreveu

\footnotetext{
7 Rodrigues 2008: 111.

8 Santos 1940 apud Lima 2010: 7-8 e Souza Jr. 2009: 48-49.

9 Republicados na coletânea organizada por Araújo 2011: 175-195.
} 
principalmente sobre o candomblé e a alimentação. Nessa temática, publicou Santo também come, em 1979, e, em 1992, Tem dendê, tem axé: etnografia do dendezeiro, obras que descrevem rituais, comidas e processos de cocção presentes em terreiros do Rio de Janeiro, Bahia, Pernambuco, Alagoas, Sergipe e Maranhão. Ainda nesse campo, há o trabalho de Vilson Caetano de Souza Junior, O banquete sagrado, publicado em 2009, que foi fruto de sua pesquisa de mestrado sobre a antropologia da alimentação ritual enfocando os pratos vegetais em terreiros Ketu de São Paulo, que descendem de terreiros baianos.

Finalmente, em 2010, foi publicado o livro da Iyalorixá Olga Francisca Régis, do terreiro Ilê Maroiá Lájin (tombado em 2008 como patrimônio cultural brasileiro), mais conhecida como Mãe Olga do Alaketu, que faleceu em 2005 com 80 anos. A comida de santo numa casa de Queto da Babia descreve os pratos e os processos de fabricação das comidas rituais de 20 divindades que são cultuadas em sua casa, conhecimentos adquiridos na prática cotidiana e herdados pela tradição oral dos fundadores, que eram integrantes da família Aro, uma das mais influentes do reino de Ketu. Com introdução e notas do antropólogo baiano Vivaldo da Costa Lima, baseadas na participação e observação continuada, elas constituem um convite para se transcender a mera descrição e classificação dos pratos em busca de um viés mais interpretativo da alimentação nos terreiros.

\section{i. Oferendas aos orixás nos terreiros Ketu de Salvador}

O fim último de um terreiro de candomblé é cultuar os orixás, o que é feito fundamentalmente a partir dos rituais de oferecimento de água e comida às representações materiais dessas divindades. Há uma cerimônia regular nesses templos, que é chamada ossé, em geral feita uma vez por mês, mas que pode ser feita toda semana para os orixás mais importantes, em que os assentamentos são limpos, as águas armazenadas nas quartinhas são renovadas, os tecidos que cobrem e vestem suas representações materiais são trocados e a chamada comida seca, composta principalmente por pratos vegetais, é preparada e oferecida. Essas cerimônias mais regulares se contrapõem às festas, que são cerimônias de peridiocidade anual em que os orixás, além da comida seca, recebem os pratos contendo parte da carne de animais sacrificados, o eran (ver Figura 1). A porção que sobra desses alimentos oferecidos aos deuses é destinada ao consumo dos membros do terreiro, dos convidados e da comunidade do entorno, em um contexto de comemoração e comunhão, que culmina com a incorporação dessas entidades espirituais nos seus fiéis. 


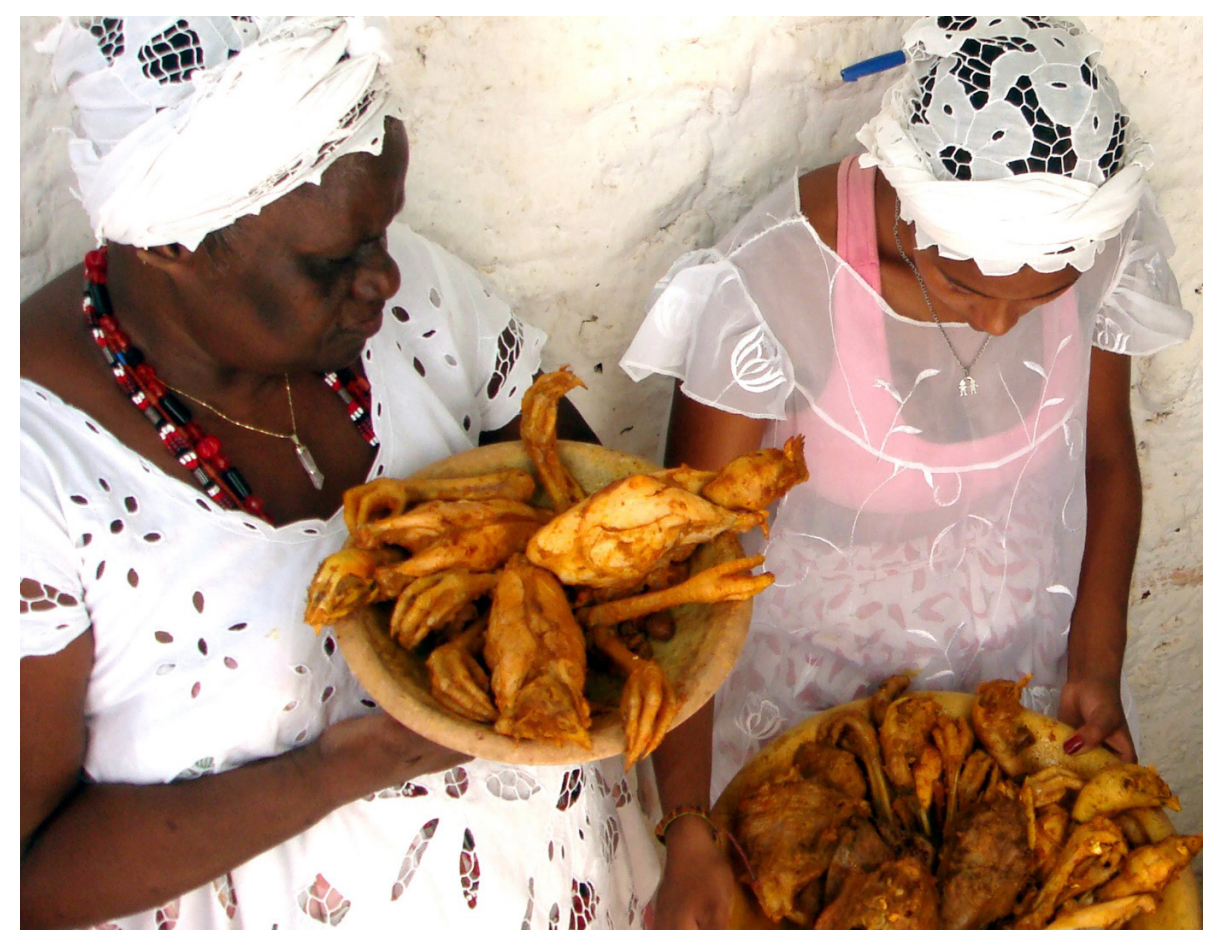

Figura 1: Comida sacrificial (eran) de Exu. Ilê Axé Opô Oyá Igbale. Recorte da fotografia de Lisy Salum

Fonte: MHLS, 2013.

O amplo sentido dado à alimentação nos terreiros de candomblé se deve principalmente à crença no axé, uma força vital presente em todos os materiais do universo, que pode ser armazenada e transferida de um ser para outro. A alimentação teria, então, um papel importante na manutenção e manipulação desse axé, para fins comunitários e sociais. Nos terreiros, todos comem, desde os orixás, as pessoas, as cabeças das pessoas, até as coisas, como os atabaques, os fios de contas e o próprio barracão ou salão, onde os orixás se apresentam ao público e dançam incorporados nos seus filhos. A iniciação de novas pessoas à religião do candomblé, ou feitura de santo, que envolve a reclusão do noviço, ou iâ, por vários dias, pode ser entendida como uma série de rituais ligados à alimentação. Primeiramente há uma cerimônia que purifica o indivíduo por meio de um "banho sem água" com grãos previamente cozidos e alimentos vegetais crus picados, que é chamado de ebó de limpeza. Ele é complementado com banhos molhados de ervas, depois dos quais se interpreta que a pessoa está livre das "más influências" e espiritualmente apta para realizar os demais processos. 
Outros rituais são de oferecimento de comida à cabeça do noviço. $\mathrm{O}$ bori é um ritual de "dar comida à cabeça", para fortalecer a ligação do corpo do indivíduo com o plano espiritual e com o seu orixá. Para os iorubás e também para o povo de santo da Bahia, a cabeça, chamada ori, é sagrada, pois é por onde nos conectamos fisicamente ao mundo espiritual. No ritual de cantação de folha, que é realizado nos terreiros Ketu que descendem do Ilê Axé Opô Afonjá, o noviço, simbolicamente comparado a uma criança, vai adquirindo o axé aos poucos e se fortalecendo com as refeições servidas à sua cabeça nas folhas de mamona, durante as celebrações feitas no terceiro, sétimo e décimo sexto dia da reclusão ${ }^{10}$.

Contudo, a principal cerimônia da feitura de santo é a realizada na saída da iniciação, em que são servidas as suas comidas sacrificiais preferidas, que provêm o axé necessário para que o novo membro manifeste o seu orixá. Ainda depois da iniciação, há que se fazer o pagamento das chamadas obrigações de santo, que devem ser dadas nos aniversários de um, três e sete anos de iniciação. Elas são nada menos do que um banquete que é servido aos pés do altar onde os assentamentos dos orixás se encontram. O significado profundo do pagamento de obrigações é aplacatório. Apesar de serem considerados a sustentação da vida e da sociedade, os orixás se tornam maus e vingativos quando deixam de receber suas comidas. Há muitos relatos no candomblé que enfatizam as consequências funestas, como doenças, perda de emprego, divórcio e até a morte, que ocorreram com quem os deixou com fome e sede.

Finalmente, depois que um membro do terreiro morre, é realizado um conjunto de complexos e demorados rituais, chamado de axexê, em que se busca conduzir a alma do defunto ao mundo transcendental para que ele siga seu caminho e não fique perturbando os vivos. Nessa cerimônia final, é realizado o carrego do falecido, ou seja, são descartadas ritualmente todas as suas parafernálias pessoais de culto. Nesse momento também são oferecidas comidas específicas para as almas dos mortos, os Eguns.

É importante ressaltar que a produção e o oferecimento de todos esses vários tipos de oferendas envolvem interação e união social. Uma máxima do candomblé diz que "não se faz candomblé sozinho", destacando a necessidade constante criada pelos rituais de unir diferentes tipos de pessoas (filhos de orixás diferentes, de idades de santo diferentes, de gêneros diferentes...) implicando conflitos, negociações, inimizades, obrigações, acordos, dissensões. Assim, podemos entender a alimentação nos terreiros de candomblé como uma atividade primordial, estruturadora das relações sociais dos seus integrantes e de sua interação com o mundo.

${ }^{10}$ Cf. fotos desse ritual realizado no Ilê Axé Opô Aganju em Mariano et al. 2009: 523-529. 
Uma oferenda para os orixás é também chamada de presente. As duas formas são usadas igualmente para designar uma relação assimétrica em que aquele que recebe tem reconhecida superioridade social em relação àquele que pede ${ }^{11}$. O presente consiste basicamente na execução e oferecimento de um prato contendo os ingredientes prediletos da entidade agraciada. Geralmente, esse prato é acondicionado em suportes de folhas vegetais, cerâmica, louça, madeira ou cestaria, além de poder ser enfeitado com flores, fitas e outros adereços. Há ocasiões em que ele é colocado no altar onde está a representação material do orixá. Em outras, é colocado em locais públicos ou terrenos baldios que tenham elementos paisagísticos relacionados com a natureza de cada entidade. Em geral, a intervenção dos orixás é solicitada nos momentos de crise e aflição. Ao entregar uma oferenda, a pessoa faz um pedido do que quer em retribuição pela comida oferecida, apelando para que a divindade se mobilize em seu favor. Nesse sentido, uma oferenda é a materialização simbólica de um desejo humano e uma forma ativa de tentar intervir na ordem cosmológica do mundo.

O conhecimento sobre a forma correta de presentear os orixás é um disputadíssimo capital simbólico. Os ingredientes de cada orixá e os modos de preparo de cada prato são conhecimentos muito valorizados dentro dos terreiros, estando entre os principais fundamentos do culto, pois toda a eficácia ritual está destinada a agradar aos orixás por meio dos seus presentes e comidas preferidos. As habilidades e competências em produzir e ofertar as comidas para eles colocam quem as possuem em evidência, o que pode levá-la a receber dos orixás um cargo, que é um título honorífico que acarreta privilégios e responsabilidades. A Iyabassê é um cargo dado exclusivamente a uma mulher experiente que fica responsável pela cozinha e por chefiar os auxiliares no preparo das comidas. Ela deve conhecer os diversos ingredientes e a forma de preparar cada alimento específico para cada orixá. Além dos ingredientes preferidos, a responsável pela cozinha tem que saber sobre as interdições alimentares, também chamadas quizilas ou euós, que são os "não alimentos", aquilo que, apesar de ser comestível, não pode ser ingerido. Muitas vezes a Iyabassê é uma filha de Oxum, pois esse orixá tem ligação com as Ajés ou Iyamis, que são as mães ancestrais, entidades arcaicas da cosmologia iorubá, muito poderosas e temidas, ligadas às forças da prosperidade nos campos, da maternidade e da feitiçaria. Entre os homens do candomblé que não entram em transe, o Axogun é o mais importante título honorífico que pode ser dado a um membro já iniciado, que, depois de se confirmar como Ogan, ou seja, tornar-se pai do orixá, tem o privilégio de segurar a faca usada na cerimônia de sacrifício dos animais. Ele deve conhecer todas as cantigas,

11 Lima 2010: 20-21. 
os gestos, as danças e as palavras que devem ser entoadas no momento de cada uma das diversas e complexas etapas desse ritual. Ele deve conhecer bem a anatomia dos animais sacrificados, pois há uma ordem e uma forma bem precisa de fazer os cortes das carnes e a separação do que vai ser dado ao santo e as partes que serão ingeridas pelas pessoas.

Nos terreiros Ketu, a alimentação ritual é tão reconhecidamente importante que até cerca de 20 anos atrás era realizada na Casa Branca a Festa do Fogão, que tinha ligação com uma qualidade especial de Oxóssi, o orixá da caça. Nessa cerimônia, o fogão a lenha comia oferendas que eram cozidas em um fogareiro de barro montado provisoriamente para esse fim e recebia presentes ligados à cozinha, como panelas e colheres. Nesse dia, o fogão "comia" e "descansava" em reconhecimento pela produção de todas as refeições dos orixás durante o ano. Depois da oferenda, a dança dos orixás, ou xirê, era feita na própria cozinha, após as entidades se manifestarem nos seus filhos para render homenagem ao fogão a lenha do terreiro.

Nos terreiros estudados, as comidas para os orixás podem ser classificadas em quatro categorias. As que são mais frequentemente oferecidas são os líquidos, sendo que a água deve estar presente próxima a todos os assentamentos de orixás, armazenadas nas quartinhas, talhas e porrões. As comidas secas são pratos de origem vegetal que levam os ingredientes preferidos de cada orixá. São oferecidos com frequência mensal, ou sempre que os assentamentos são limpos. O ejé ou sangue sacrificial é a comida que possui maior quantidade de axé. Por isso, geralmente é servido anualmente, acompanhado pelas penas, cabeça, patas e vísceras dos animais sacrificados. Dentre as categorias alimentares, devemos ainda mencionar uma quarta, que são os alimentos apenas mastigáveis, de caráter digestivo ou estimulante, que geralmente não são mencionados pelos pesquisadores, mas o contato com as celebrações dos terreiros mostra que é um elemento muito importante. Câmara Cascudo afirma que especialmente o africano ocidental tinha o hábito de mascar folhas, raízes e nozes ${ }^{12}$. Na Bahia, esse hábito, que está em extinção no cotidiano, ainda está bem preservado de forma ritual nos terreiros de candomblé Ketu. É costume se mascar atarê, a pimenta da costa africana, cujo significado é possivelmente apotropaico, pois as pimentas em geral são quizilas das $A j e ́ e^{13}$. Além do atarê, é como comum o oferecimento do obi (noz de cola) ao orixá depois que termina o ritual de sacrifício dos animais. Nessa situação, o obi tem ativa ligação com o mundo espiritual. Depois de cortado em quatro, o sacerdote faz perguntas para a entidade que acabou de comer, sendo que a questão mais comumente levantada é se ela está satisfeita com o que lhe foi

\footnotetext{
12 Cascudo 2004: 225.

13 Verger 1992: 5-91.
} 
oferecido. Deixando cair no chão ou em um prato branco as quatro partes do obi, de acordo com o número de partes para cima ou para baixo, o sacerdote reconhece a resposta do orixá. Nesse momento, a entidade pode dizer que está satisfeita com aquilo que foi ofertado ou cobrar uma oferenda maior, o que é comum, por exemplo, quando os devotos oferecem uma ave, bicho de dois pés, e o orixá diz que para matar sua fome é necessário oferecer um bicho de quatro pés, geralmente um bode ou cabra, que é bem mais caro do que os galináceos. Nesse momento de comunicação, os orixás frequentemente dão conselhos, efetuam cobranças e receitam ebós para os seus filhos de santo ensinamentos que, simbolicamente, são recompensados com a oferenda de dinheiro, que é usado posteriormente para o pagamento das despesas do ritual. Esse método de comunicação com os orixás usando-se dos cotilédones da castanha do obi é originário dos iorubás africanos e também foi observado em comunidades afro-cubanas ${ }^{14}$.

As quatro categorias de alimentos são oferecidas juntas aos orixás nas suas festas anuais, quando alguém é iniciado ou está pagando alguma obrigação, ficando bem clara a semelhança com um banquete (ver Figura 2). Os banquetes com significados religiosos são encontrados em muitas sociedades, desde as primeiras civilizações, como, entre outras, as da Mesopotâmia, cerca de 3000 a. C. Nessas sociedades antigas, a celebração de banquetes era uma das principais marcas de solidariedade dos homens entre si e com os deuses, ao mesmo tempo em que atualizavam práticas culturais do grupo e reforçavam suas posições hierárquicas ${ }^{15}$. Essas características também podem ser observadas nos terreiros, o que mostra que a alimentação ritual tem raízes muito profundas na trajetória de humanidade.

\footnotetext{
14 Lima 2010: 47.

15 Joannès 1998: 64-67.
} 


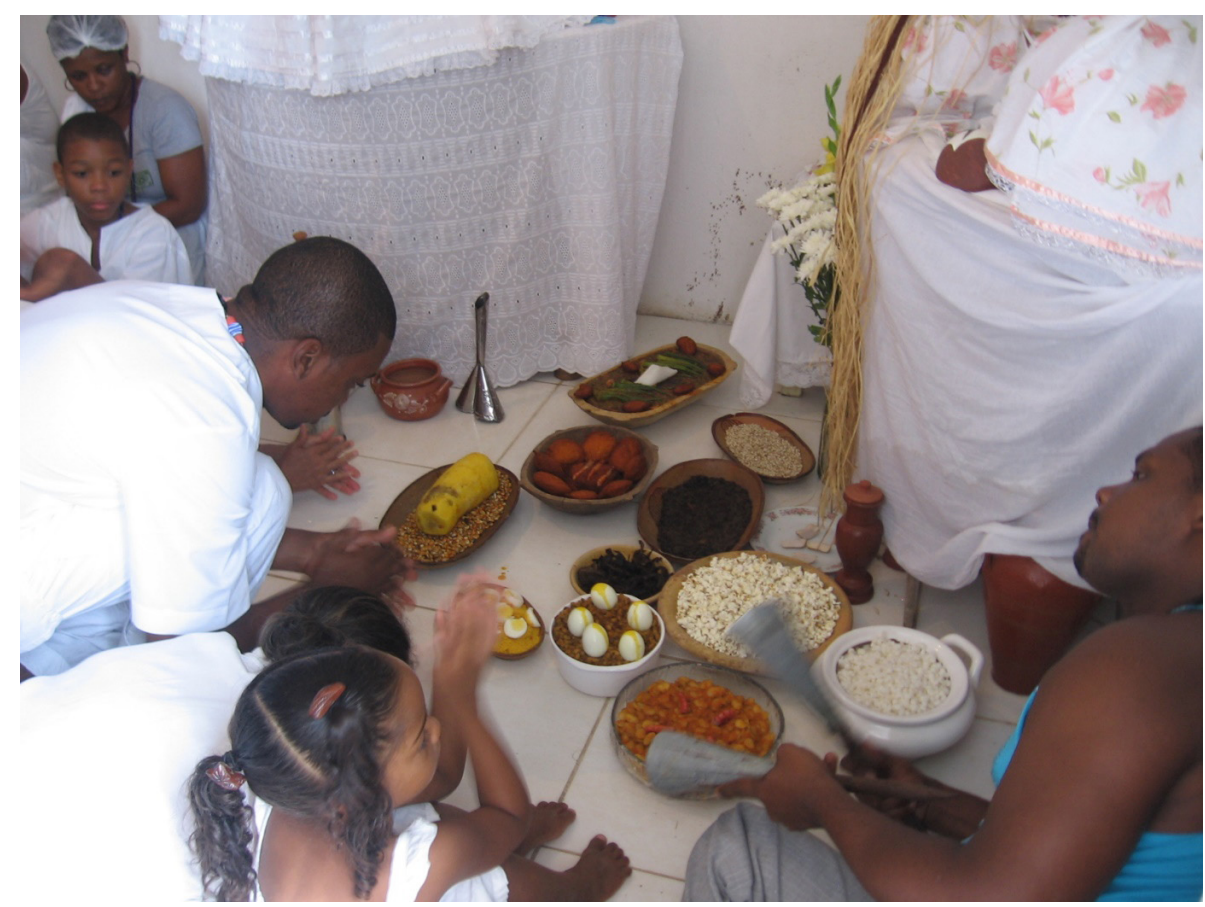

Figura 2: Obrigação de um ano de Ogan de Omolu (sem eran). Ilê Axé Opô Oyá Igbale. Fonte: ARJ, 2011.

A seguir, vamos apresentar, de forma sucinta, alguns alimentos típicos dos dez mais conhecidos orixás dos terreiros Ketu de Salvador, a maioria já descrita ou referida pelos pesquisadores que citamos, mas raras vezes mostrados. Os pratos são usualmente descritos, mas não fotografados. Aqui é importante destacar que, nos candomblés mais antigos, não são feitas fotografias no momento dos rituais devido ao perigo de elas revelarem as peculiaridades, os fundamentos do culto. Dessa forma, só é permitido fotografar algumas celebrações nos terreiros mais novos, menos reticentes ao seu uso, mas ainda assim com prévia autorização do dirigente, que avalia o que pode ser fotografado e divulgado. Nas imagens que se seguem, aparecem apenas comidas bem conhecidas do povo de santo, quase todas tiradas antes de irem para o altar. As fotos das comidas dos assentamentos, quando visíveis, são todas de locais externos, onde qualquer pessoa que participasse da festa, independentemente de ser iniciada ou não, poderia vê-las.

Começamos por Ibeji, o orixá gêmeo. Nos candomblés, o seu principal prato é o caruru, uma comida feita com quiabos finamente cortados, temperados com azeite de dendê, cebola ralada, camarão seco, leite de coco, amendoim e castanha de caju ralados. O caruru é o prato principal, que é acompanhado 
geralmente por farofa de dendê, vatapá, feijão fradinho, feijão preto, acarajé, abará, xinxim de galinha, batata doce, pedaços de cana, lascas de coco, pipoca e milho branco cozido. Além deles, a representação material de Ibeji e as crianças presentes ganham também variados tipos de doces e brinquedos. Nos terreiros, o caruru é primeiramente servido às representações materiais do orixá. Em seguida, as sete primeiras crianças comem juntas sentadas em uma esteira, e só depois as demais crianças e os adultos são servidos. A origem do caruru é obscura. Alguns autores o consideram uma forma de comida indígena, que pode ter sido levada para o outro lado do Atlântico e influenciado sociedades africanas. O caruru é, na verdade, não um prato, mas um modo de preparo de vegetais frescos, sendo que a receita que usava quiabos ficou mais conhecida e se tornou a preponderante, mas no passado também podia ser feita com mostarda, taioba, unha de gato e bertalha ${ }^{16}$. Essa comida dos terreiros é a mesma que é produzida no dia 27 de setembro pela população baiana em geral para pagar promessas feitas a São Cosme e Damião, santos aos quais Ibeji corresponde no sincretismo religioso. Talvez por isso as comidas de Ibeji sejam as comidas de santo mais consumidas entre a população de Salvador.

Exu é um dos principais orixás do panteão iorubá. É o intermediário entre os homens e os outros orixás e o responsável pela evolução do mundo. Sem a ajuda e o consentimento de Exu, nada acontece. Por razões mitológicas, ele tem que comer sempre antes de qualquer outro orixá, por isso é o que mais come. Como disse mãe Olga do Alaketu, "Exu come de tudo. Come com os outros santos. Todos os santos que comem dão um quinhão a Exu"17. Mas a comida mais tradicional é sem dúvida a farofa de azeite de dendê (ver Figura 3). Das 25 comidas listadas por mãe Aninha do Ilê Axé Opô Afonjá em 1937, apenas a "farofa" não foi escrita em iorubá. A etimologia da palavra "farofa" é bastante discutida, e os filólogos ora associam-na ao latim, remetendo à ideia de um esfarinhado, ora associam-na ao quimbundo, designando a mistura de farinha, azeite e água ${ }^{18}$. Câmara Cascudo escreve que farofa, também falado farófia, como faz Dona Olga, vem do quimbundo falofa, que significa "preparar com ingredientes frios" ou "sem a intervenção do calor". Ele ainda menciona que a falofa primitiva angolana era feita com fubás de sorgo e milhetos, até que foram substituídos, no século XVI, pela "farinha de pau", a raiz da nossa nativa e tão consumida mandioca. Entretanto, ele não consegue entender a razão da etimologia da palavra remeter ao preparo a frio, sendo que em todo Brasil e em Angola as farofas comidas no cotidiano são idênticas e feitas no

\footnotetext{
${ }^{16}$ Querino 2011: 38-39.

17 Régis 2010: 11.

18 Lima 2010: 31.
} 
calor $^{19}$. Mas esses dados fazem sentido quando lembramos que a principal cerimônia de dar comida a Exu nos candomblés Ketu chama-se padê, que é feita sempre antes do início de qualquer festa para os orixás. Essa cerimônia é muito temida e por isso executada com o todo o cuidado muitas horas antes da chegada dos convidados. Essa comida é preparada a frio, no próprio barracão do terreiro, não na cozinha, por duas mulheres que misturam em cuias a farinha de mandioca, em três partes distintas, com água, cachaça e azeite de dendê. Em seguida, ela é ofertada a Exu nos pés de uma árvore, acreditando-se que, por ter recebido sua oferenda, ele permitirá a festa e a vinda dos outros orixás. Desse modo, pode ser que a comida de Exu aqui no Brasil, nos terreiros Ketu, tenha vindo pelas tradições dos povos bantos da África Centro-Meridional, que também foram trazidos em grande quantidade para Salvador antes da vinda massiva dos iorubás, pois eles também cultuavam entidades com um arquétipo semelhante a Exu, como o inquice Bombogira.

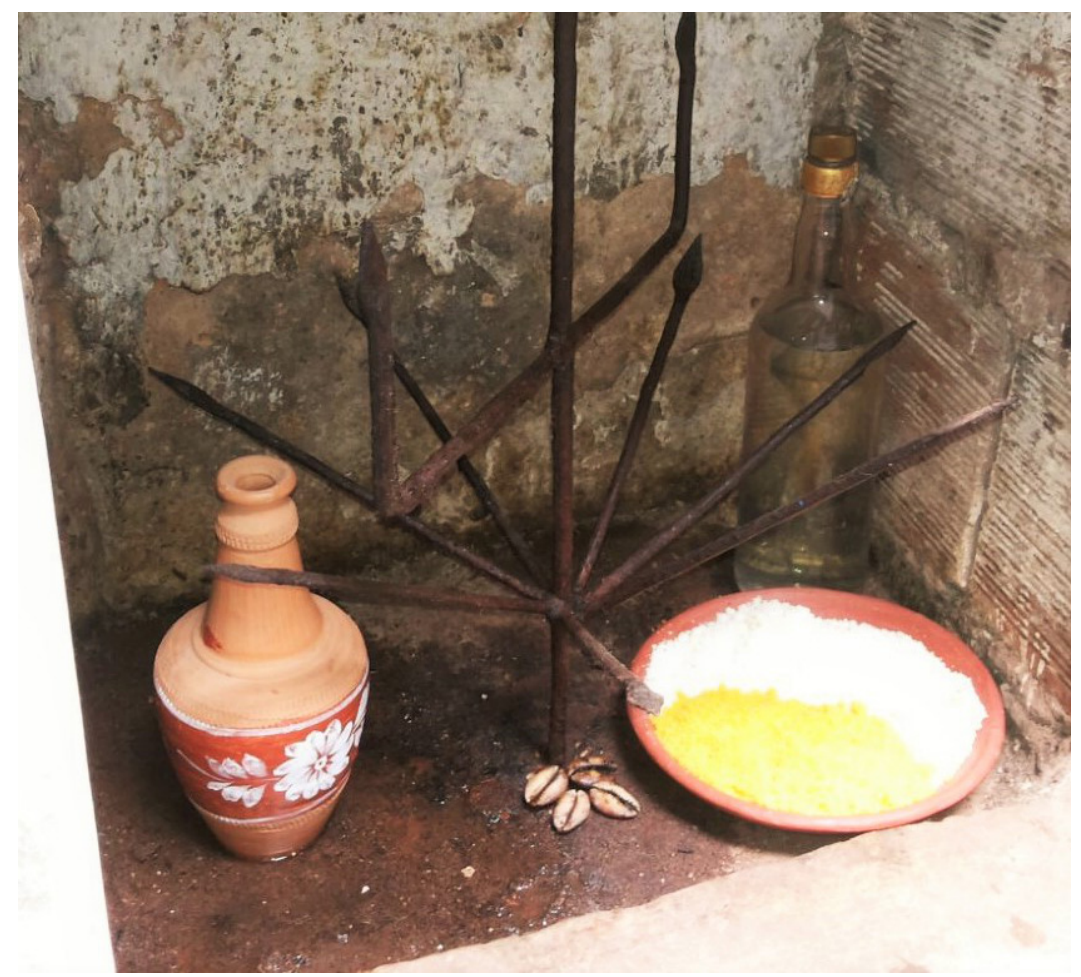

Figura 3: Farofa oferecida ao assentamento de Exu. Ilê Axé Opô Oyá Igbale.

Fonte: Jairo José de Oliveira Barros Junior, 2015.

${ }_{19}$ Cascudo 2002: 101-3. 
Exu, entre os iorubás da África, tomava o vinho de palma, chamado de emu, que é uma bebida fermentada a partir da seiva de uma palmeira. Também era consumido na Bahia no início do século $\mathrm{XX}^{20}$. Atualmente, com a extinção do emu em Salvador, a bebida alcoólica que Exu mais bebe é a cachaça, que tradicionalmente era produzida nos engenhos de açúcar do Recôncavo Baiano. Atualmente, ela é ainda produzida de forma artesanal em inúmeros alambiques em áreas rurais do Brasil, mas principalmente em escala industrial. Em tempos mais recentes, alguns integrantes de terreiros passaram a ofertar uísque a Exu em suas oferendas pessoais, numa tentativa de enobrecer sua bebida principal, tendo em vista que a cachaça tem conotação de ser bebida vulgar. Outro agrado muito apreciado por Exu é o tabaco, que pode ser adicionado sob a forma de charuto em cima do prato, como enfeite. Entre os iorubás, na África, Exu é considerado um ser extremamente poderoso, por fazer parte de uma classe de entidades que são arcaicas, pois aparecem logo no início das teogonias e geralmente são possuidoras tanto do princípio masculino quanto do feminino, sendo que, para Exu, essa completude adquire materialidade pela sua representação por duas esculturas antropomórficas, uma masculina fazendo par com outra feminina ${ }^{21}$. Já no Brasil, as figurações de Exu são cultuadas separadas. É comum vermos os integrantes do candomblé chamando o aspecto feminino dessa entidade como Exua, Exu de saia ${ }^{22}$, ou até mesmo Padilha, que é uma divindade cujo arquétipo se assemelha a Exu, mas que é geralmente cultuada em outra religião afro-brasileira, a Umbanda. Quando se oferece presentes a um Exu do gênero feminino, geralmente se substitui o galo por uma galinha, a cachaça por vinho branco ou espumante alcoólico e o charuto por cigarro ou cigarrilha. Quando as oferendas para Exu são ofertadas fora do terreiro, é costume colocá-las em ruas, estradas e encruzilhadas, pois ele está associado com o movimento, o dinamismo e as comunicações.

Ogun é o orixá do ferro e da guerra, tido como o abridor de caminhos e o patrono da tecnologia. Os mitos contam que foi um dos primeiros orixás a chegar à terra, pois ele vinha abrindo o caminho com seu facão. Por isso, junto com Exu, é um dos primeiros a ser reverenciado. Há duas comidas bastante comuns que são feitas nos terreiros Ketu para Ogun: o inhame assado e o axoxó, que muitas vezes aparecem combinados, o primeiro por cima do último. O inhame é assado, descascado e untado com uma mistura de azeite de dendê, mel e sal (ver Figura 4). Às vezes, é ofertado inteiro, outras vezes, aberto, cortado ao meio longitudinalmente. $\mathrm{O}$ axoxó é feito à base de grãos

\footnotetext{
20 Querino 2011: 45.

${ }^{21}$ Cunha 1983.

22 Lima 2010: 35.
} 
secos de milho amarelo, que descansam em água com sal antes de serem tostados. Em cima do milho, cortam-se fatias de coco, que são dispostas de forma esteticamente harmoniosa. Vê-se, nesse prato, que o milho, uma planta americana, foi associado ao coco, fruto de uma palmeira asiática que se desenvolveu muito bem no nordeste do Brasil, onde é conhecido como coco da Babia, dando uma combinação que se repete em vários pratos da culinária cotidiana brasileira ${ }^{23}$. Fora dos terreiros, é comum observarmos o oferecimento de inhames para Ogun nas ruas, estradas, linhas férreas e também nos galhos das palmeiras do dendezeiro. O inhame é um tubérculo muito consumido pelas populações da África Ocidental e Meridional, algumas das quais realizam grandes festas nas épocas de sua colheita.

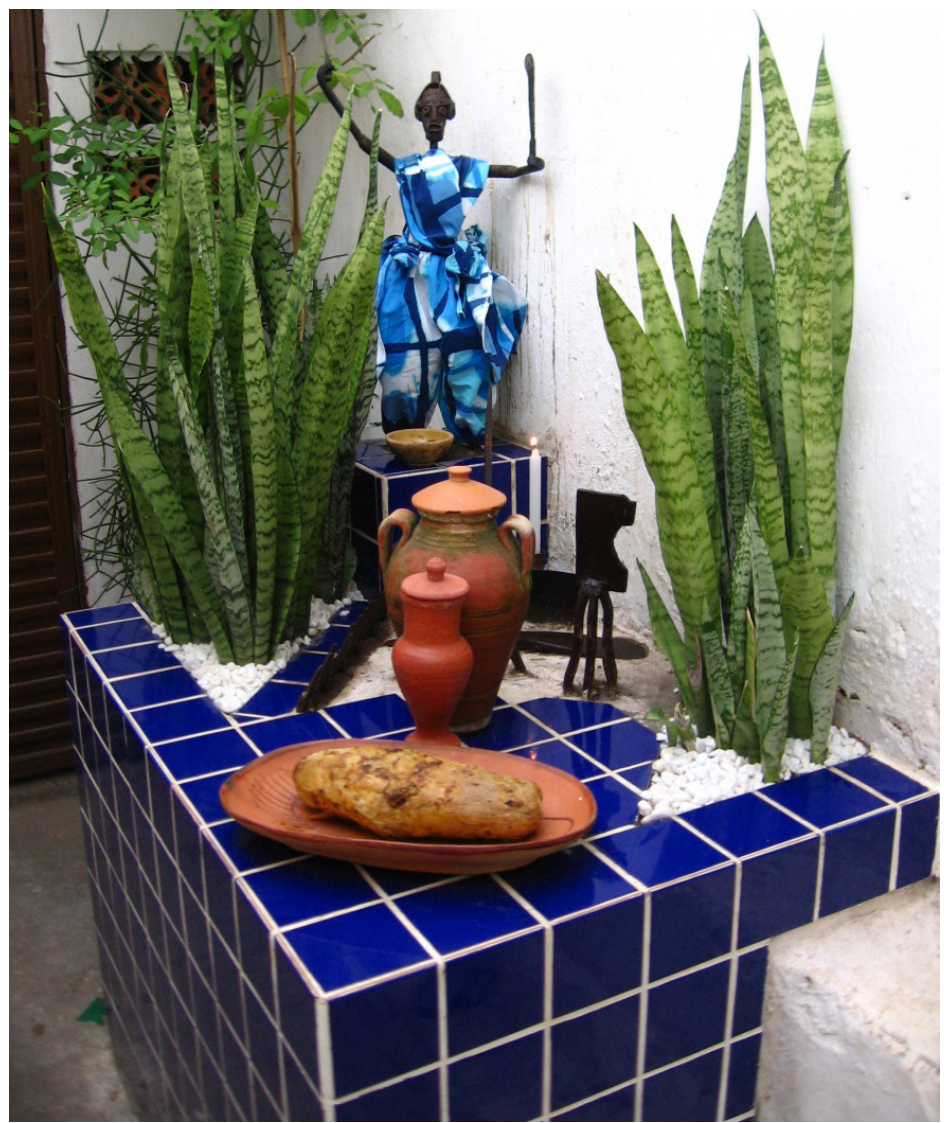

Figura 4: Inhame oferecido ao assentamento de Ogun. Ilê Axé Opô Oyá Igbale. Fonte: ARJ, 2013.

${ }^{23}$ Cf. Cascudo 2002. 
Omolu é tido como um espírito muito antigo e rústico, anterior aos orixás ${ }^{24}$. Ele tem controle sobre a varíola e, por extensão, sobre todas as doenças que acometem os homens. Cobre-se de palha para que não vejam as chagas da doença em seu corpo. A crença de que Omolu pode curar moléstias deve explicar a persistência e o vigor do seu culto na Bahia. Nina Rodrigues relata que, nas épocas de epidemias, na transição do século XIX para o XX, Salvador amanhecia com as ruas e encruzilhadas cobertas de milho torrado, pilado ou não, com azeite de dendê, sugerindo que essa oferenda era a mais corriqueira na época ${ }^{25}$. Atualmente, o alimento predileto para Omolu é o milho de pipoca estourada em panela de barro, às vezes com um pouco de dendê, o que as deixa com uma cor alaranjada. É interessante observar uma entidade, cujo culto na África parece ser mais disperso e antigo que o culto aos orixás, ter um alimento nos terreiros que não é africano, mas sim americano. Talvez razões simbólicas e mitológicas tenham tido maior importância no momento de substituir o que ele comia na África com o que estava disponível aqui, pois a forma da pipoca estourada pode ter sido associada às feridas que Omolu tinha na pele, conforme relatam os mitos. É costume também se jogar pipoca sobre esse orixá quando ele está incorporado em seus filhos, como forma de saudá-1o. O banho de pipocas é também um dos itens muito usados nos rituais de purificação dos terreiros. Nas escadarias da Igreja de São Lázaro, em Salvador, é muito comum praticantes de religiões afro-brasileiras e até de outras religiões tomarem banho de pipoca perante o cruzeiro da igreja, como ritual de limpeza. Há uma festa realizada nos terreiros Ketu, feita em homenagem a Omolu, chamada Olubajé, em que é servido um banquete contendo a comida de todos os orixás. Porções de todos esses pratos são servidos envoltos em folhas de mamona. Essa comida é tida como um ebó (um feitiço) para a saúde. Caso a pessoa não queira comer, convém receber a comida, passá-la em volta do corpo para retirar as energias relacionadas às doenças e colocá-la num cesto, que será ritualmente descartado com todas as sobras desse banquete em um bosque ou em outro local apontado pelo jogo de búzios. O fato de ser considerado um orixá infecto cria cuidados especiais de quem prepara sua comida. $\mathrm{Na}$ Casa Branca, "as fartas comidas de Obaluaiê não podem ser preparadas na cozinha ritual comum. Para sua festa, uma cozinha é montada em sua própria casa" ${ }^{26}$. No Ilê Axé Opô Aganju, as comidas para Omolu são feitas na cozinha comum do terreiro, entretanto, toda parafernália (panelas, colheres de pau, alguidares etc.) é exclusiva dele. Nesse caso, há também a preocupação dos responsáveis por sua casa para que as panelas de Omolu

\footnotetext{
24 Souza Jr. 2009: 128.

25 Rodrigues 2008: 209.

26 Soares 205: 118.
} 
não sejam emprestadas para outros orixás e "contaminadas" com alimentos proibidos para ele, principalmente com sangue sacrificial de carneiro, que é uma das quizilas mais fortes desse orixá nesse terreiro.

Oxóssi é o orixá caçador e por isso é associado à fartura. Segundo os mitos, foi ele quem fundou Ketu, um importante reino iorubá de onde vieram sacerdotisas e sacerdotes que implantaram o culto a esse orixá no terreiro da Casa Branca, na Bahia ${ }^{27}$. Os pratos principais de Oxóssi são o feijão fradinho tostado e o mesmo axoxó que é dado a Ogun, talvez por serem orixás irmãos. No terreiro de Olga do Alaketu, o axoxó de Oxóssi se diferencia do de Ogun porque é feito com milho branco ${ }^{28}$. Entre as comidas sacrificiais dadas aos orixás, as de Oxóssi chamam atenção pela quantidade e variedade. $\mathrm{Na}$ Casa Branca, ele é o único que come regularmente um boi, a maior oferenda que um orixá pode ter. Essa festa é realizada na quinta-feira de Corpus Christi. O feijão de Oxóssi, feito com as partes desse boi, são saboreados por todos os integrantes e visitantes que participam dessa que é uma das mais importantes celebrações da Casa Branca. Já entre os terreiros descendentes do Ilê Axé Opô Afonjá, o boi também é oferecido, além do porco e também animais "de caça” e exóticos, como coelho, iguana, tatu e faisão. Mãe Olga do Alaketu diz que na casa dela Oxóssi come qualquer caça, exceto sanhaço, urubu e coruja, provavelmente pela associação simbólica com os Eguns e Ajés ${ }^{29}$. Outro elemento que chama atenção nos presentes para Oxóssi são as frutas, que não são comuns como oferendas dentro dos terreiros de candomblés. Talvez seja para simbolizar os matos e as florestas onde esse orixá costuma caçar, mas também pode ser a apropriação de formas rituais de oferendas aos caboclos, que também são seres da floresta, pois são os espíritos dos índios nativos e dos seus descendentes, mas feitas principalmente nos terreiros de tradição Angola de Salvador. Nessas festas, é oferecida uma quantidade de frutas que posteriormente são distribuídas entre a comunidade. Quando se observam as oferendas de frutas realizadas na festa de Oxóssi de Mãe Estela do Ilê Axé Opô Afonjá, por exemplo, não dá para deixar de fazer a associação com as oferendas feitas para os caboclos. Outra que é muito característica, tanto para os caboclos quanto para Oxóssi, é a espiga de milho, que simboliza a fertilidade dos campos e a fartura. Um babalorixá afirmou que "quando você vê uma espiga de milho, você obviamente lembra de Odé [caçador]" ${ }^{30}$. Mas as espigas de milho em Salvador também são ícones dos caboclos, que também as recebem como presentes. Depois que o ritual acaba, as espigas são levadas pelos integrantes, que as colocam atrás da porta principal de suas

\footnotetext{
${ }^{27}$ Verger 1981: 114-115.

28 Régis 2010: 45.

29 Régis 2010: 45.

30 Souza Jr. 2009: 126.
} 
casas, usadas simbolicamente para proteger e garantir o sustento da família. A espiga seca só é trocada no ano seguinte, depois da execução da próxima festa. Isso reforça a impressão de entrelaçamento cultural, nos terreiros de candomblé Ketu, com antigas tradições dos terreiros de Nação Angola e com religiosidades indígenas. As oferendas para Oxóssi, quando feitas fora dos terreiros, geralmente são postas no interior de um matagal, bosque, floresta, ou até mesmo na rua.

Xangô é orixá do fogo, do trovão e da justiça, conhecido por usar um machado de dois gumes. Os mitos dizem que ele foi herdeiro do trono de Oyó, um importante reino iorubá que, no século XVIII, se tornou o centro de um império. Por ter sido soberano de um reino tão próspero, é um orixá associado ao luxo palaciano, que se opõe aos orixás da rua, como Exu, Ogun, Omolu e Oxóssi, que são considerados mais rústicos. Essa oposição toma concretude na alimentação ritual, na qual o recipiente preferencial usado para ofertar comida para Xangô é a gamela de madeira, que é mais fina e cara do que as cerâmicas vulgares torneadas que são usadas para esses outros orixás. $\mathrm{O}$ preço mais caro do seu animal sacrificial predileto, o carneiro, também pode ser um símbolo de sua imponência. $\mathrm{O}$ ciclo de festas para Xangô nos terreiros antigos da nação Ketu geralmente dura 12 dias. Há uma cerimônia muito famosa, chamada $A j e r e$, em que os orixás, incorporados em seus filhos, reencenam o mito que conta como Iansã se apoderou do poder do fogo de Xangô, que era guardado dentro de uma panela de barro. Essa cerimônia é sempre interna no Ilê Axé Opô Afonjá, realizada dentro do quarto de Xangô, mas, no Ilê Axé Opô Aganju, algumas vezes é realizada no barracão. Nela, esses orixás literalmente comem o fogo, engolindo chumaços de algodão em chamas. A comida seca preferida de Xangô é o amalá, que é uma espécie de mingau feito com quiabos cortados longitudinalmente em cruz e depois picados em rodelas finas, que são temperados com azeite de dendê, camarão, cebola, sal e bastante pimenta vermelha. É comum deixar 6 ou 12 quiabos inteiros no meio da mistura para serem servidos como enfeite simbólico na cobertura do prato ofertado (ver Figura 5). A gamela de madeira usada para servir é untada previamente com uma camada espessa de angu de farinha de mandioca. A decoração pode ser feita com porções pequenas de acarajés ou acaçás. Existem muitas variações desse prato, que são feitas em ocasiões especiais ou para qualidades diferentes de Xangô. Nesses amalás, podem entrar ingredientes não comestíveis na composição do prato, como moedas, seixos e capins. É surpreendente que a receita baiana atual seja quase sempre referida com quiabos, enquanto o amalá comido atualmente na Nigéria é feito sobretudo com farinha de inhame. Consultando os autores, vemos que os pioneiros Nina Rodrigues e Manuel Querino não citam essa comida, apenas o caruru. Artur Ramos o cita rapidamente como um prato à base de 
quiabos, "uma espécie de caruru", que teria sido apresentado em 1934 no I Congresso Afro-brasileiro por sacerdotes de terreiros ${ }^{31}$.

$\mathrm{Na}$ relação de comidas de candomblé de Mãe Aninha, nos Anais do II Congresso Afro-brasileiro, em 1937, o amalá aparece e está referido como feito com quiabos ${ }^{32}$. Nos terreiros estudados por Vilson Caetano, essa comida é referida como "iguaria à base de inhame ou milho, servida com quiabos" ${ }^{33}$. Mãe Olga do Alaketu diz que, em seu terreiro, é um "angu de inhame, ou de farinha, ou de acaçá", mas que ele não pode ser servido "puro", mas sim coberto de "caruru". A partir de evidências linguísticas e etnográficas, Vivaldo da Costa Lima confirmou que o amalá nigeriano é feito à base de inhame, e inferiu que aqui "o nome da base da comida, da base estrutural do prato, se estendeu para a toda a comida" 34 . Ou seja, a cobertura, que é muito mais saborosa, com o passar do tempo acabou se tornando a parte principal do prato. Uma diferença de Xangô em relação aos outros orixás é que ele não come obi, pois, segundo os mitos, foi em um dendezeiro que ele se enforcou e voltou para o orun, o mundo transcendental. Dessa forma, na hora de se consultar se o orixá está satisfeito com as oferendas, o obi tem que ser substituído pelo orobô, que é uma castanha de outra palmeira. Quando se oferece amalá para Xangô fora dos terreiros, geralmente escolhem-se pedreiras e lugares altos.

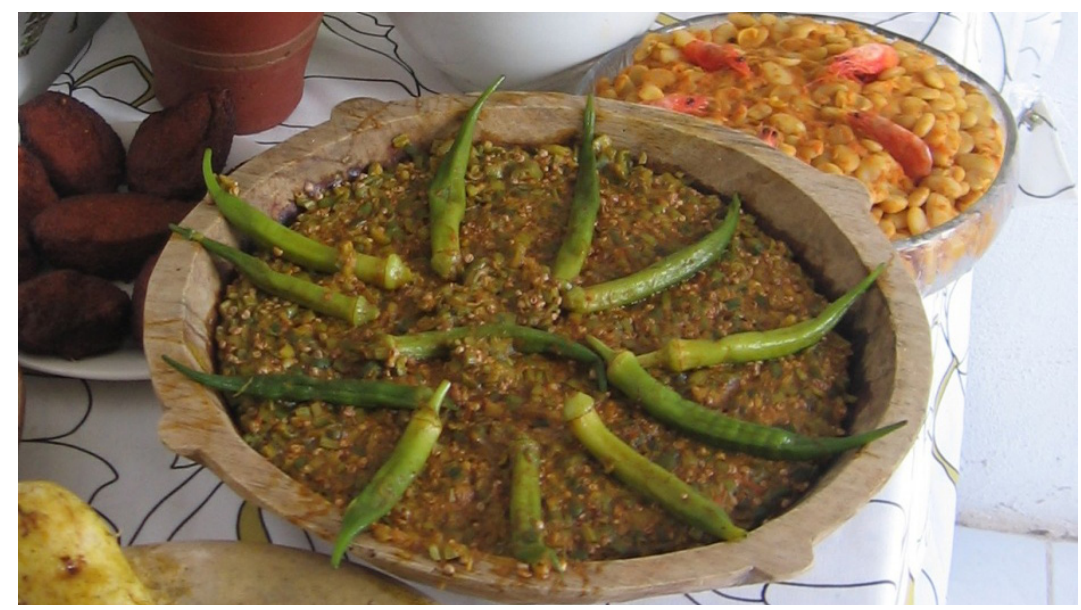

Figura 5: Amalá de Xangô. Ilê Axé Opô Oyá Igbale.

Fonte: ARJ, 2015.

\footnotetext{
31 Ramos 2008: 109.

32 Santos 1940 apud Souza Jr. 2009: 49 e 155.

33 Souza Jr. 2009: 155.

34 Lima 2010: 64-65.
} 
Iansã é a deusa dos ventos, relâmpagos e tempestades, a mulher preferida de Xangô, que lhe roubou o segredo do fogo. Sua comida preferida é o acarajé, cuja origem iorubá significa "bola de fogo". Esse alimento é um bolo feito de feijão fradinho sem casca, ralado, temperado com bastante cebola moída e sal (ver Figura 6). Essa massa é bem batida e depois frita em óleo de dendê bem quente, que faz com que o aroma do bolinho fritando se espalhe por uma grande distância. $\mathrm{O}$ acarajé pode ser enfeitado com camarões secos. Esse bolinho é um prato típico em Salvador, feito e vendido pelas "baianas de acarajé" e registrado como patrimônio cultural intangível brasileiro em $2005^{35}$. Depois que os bolinhos são fritos, são arrumados em um prato em número de nove, que pode simbolizar os nove pedaços em que Iansã foi cortada ou o número de filhos que teve, segundo os mitos. Por ter ligação com Xangô e também com Oxóssi, as oferendas para Iansã são postas também em pedreiras e matos. Sobre os acarajés consumidos no cotidiano baiano, Raul Lody aponta que aumentaram de tamanho no pós-guerra, em virtude da influência da cultura estadunidense, época que apareceram as variedades de molhos e a salada de acompanhamento, tornando-se mais parecidos com um sanduíche ${ }^{36}$.

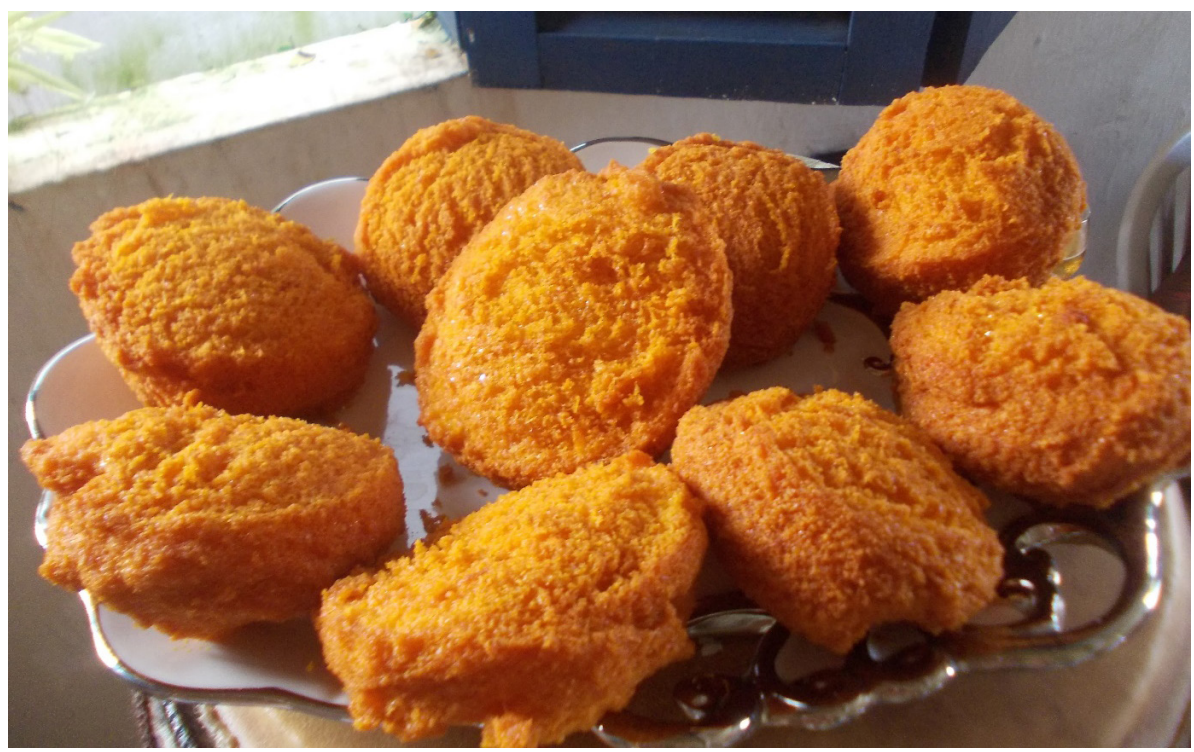

Figura 6: Acarajé de Iansã. Ilê Axé Opô Oyá Igbale.

Fonte: ARJ, 2015.

\footnotetext{
35 Iphan 2007.

${ }^{36}$ Lody 1998: 155.
} 
Oxum é a deusa das águas doces. Segundo os mitos, apesar de ter sido casada com Xangô e Ogun, foi a mulher preferida de Oxóssi. Sua comida predileta nos terreiros Ketu é o omolokun, feijão fradinho cozido, temperado com azeite de dendê, cebola e camarão seco macerados (ver Figura 7). $\mathrm{O}$ uso desse feijão deve ser uma referência a Oxóssi, pois o fradinho tostado, como vimos acima, é um de seus pratos preferidos. O omolokun deve ter sido um prato consumido de forma habitual no passado, pois Manuel Querino o cita em seu livro, chamando-o de "feijão de azeite" ${ }^{37}$. Nos terreiros Ketu, o omolokun é adornado com ovos cozidos de galinha (ou de codorna, dependendo da qualidade da Oxum que vai ser agraciada), que são manchados na ponta com um pingo de azeite. Essa decoração parece ser uma referência às Ajés, que, segundo os mitos, têm o poder de metamorfosearem-se em pássaros. Além do omolokun, outra importante comida, que é feita somente uma vez durante o ano em uma importante festa, é o ipeté, composto por inhame cozido e amassado, temperado com azeite de dendê, cebola e camarão seco moídos. As oferendas para Oxum nas áreas externas são postas em locais de água doce, como nascentes, lagoas e rios.

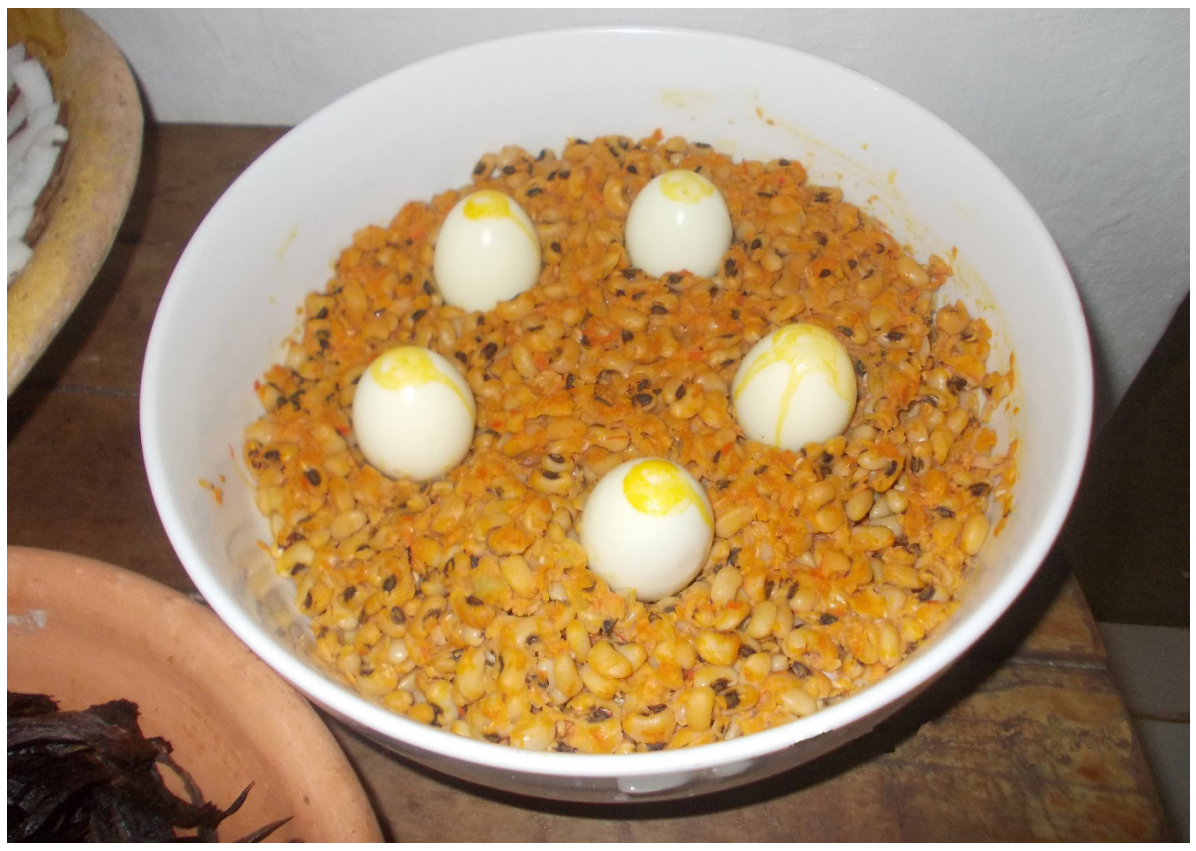

Figura 7: Omolokun de Oxum. Ilê Axé Opô Oyá Igbale.

Fonte: ARJ, 2015.

37 Querino 2011: 40. 
Iemanjá é mãe de todos os orixás, associada às águas salgadas. Nos terreiros Ketu, as oferendas externas para Iemanjá são feitas no presente das águas, que é a cerimônia final de um ano litúrgico, ocasião em que se agradece pelo ano que se passou e se pede prosperidade para o próximo, oferecendo-se os principais pratos desses orixás. No presente das águas, além de Iemanjá, também são ofertados presentes para Oxum e para Oxalá. A comida preferida de Iemanjá é a fava cozida temperada com azeite de dendê, cebola, sal e camarão seco (ver Figura 8). A fava, que é mais cara e difícil de encontrar, pode ser substituída também pelo milho branco cozido. Nos terreiros estudados, o presente das águas é feito em áreas de fozes de rios, como a praia do Rio Vermelho, em Salvador, e a barra do Rio Jacuípe, em Camaçari. Certamente essa escolha levou em consideração a procura por um ambiente que satisfizesse simbolicamente aos três orixás, um lugar em que a água doce encontra a água salgada, já que os três são homenageados juntos nessa ocasião. Atualmente, é bem popular em Salvador a cerimônia de entrega de presentes para Iemanjá realizada pelos pescadores do bairro do Rio Vermelho, que são auxiliados por lideranças de candomblé. Nessa ocasião, além das flores e perfumes que são ofertados diretamente na praia pelos frequentadores, muitos presentes são preparados, juntados e ofertados em vários cestos, enfeitados com flores e fitas, e perfumados com água de lavanda. Mas o principal sempre é um prato com a comida preferida do orixá que fica escondida no seu interior. $O$ presente é levado em barcos até um local que os pescadores afirmam que há uma fenda no fundo do mar. Interpreta-se o afundamento dos cestos como sinal que foram aceitos pela rainha do mar, o que renova as bênçãos e as esperanças para a pesca.

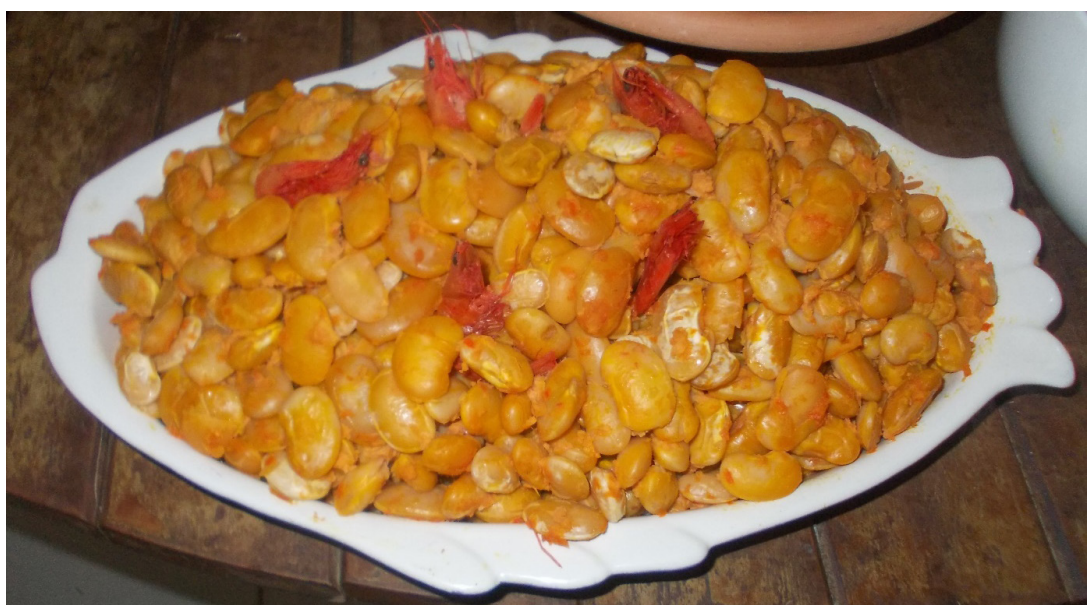

Figura 8: Comida de Iemanjá. Ilê Axé Opô Oyá Igbale.

Fonte: ARJ, 2015. 
Finalizando a descrição das comidas oferecidas, Oxalá é o pai de todos os orixás e o criador dos seres humanos. É um dos seres mais poderosos do panteão iorubá, rivalizando com Exu, de quem ganhou a acirrada disputa justamente porque fez todas as oferendas que haviam sido prescritas por um babala $\hat{o}^{38}$. Todas as suas roupas e comidas devem ser brancas, seus pratos só contêm alimentos brancos e nunca se coloca dendê, sal e pimenta em suas comidas. $\mathrm{O}$ azeite de dendê deve ser substituído por banha de ori, um óleo vegetal à base de manteiga de karité, mas que, às vezes, pela dificuldade de consegui-lo, costuma ser substituído por azeite de oliva. Os rituais dedicados a esse orixá nos terreiros Ketu são denominados Águas de Oxalá, bastante complexos e que duram vários dias. Nessa ocasião, os integrantes do terreiro devem recolher água de uma fonte e carregá-la em talhas e porrões até os assentamentos para que as águas armazenadas nas quartinhas, talhas e porrões sejam renovadas. A base da alimentação oferecida a esse orixá é o milho branco cozido sem sal. Desse milho cozido faz-se o acaçá, que é uma espécie de massa de milho branco embalada em folhas de bananeira. O nome acaçá é de origem fon e era a base alimentar e religiosa no Daomé3 ${ }^{39}$. Entre os iorubás, ele é conhecido como ecó. É o alimento mais usado e polissêmico dos terreiros, empregado em muitos rituais e que pode ser oferecido como acompanhamento da comida de todos os outros orixás, incluindo Exu. Outra comida de Oxalá que se impõe sobre todos os outros são as pombas brancas, que são obrigatórias em todas as iniciações. $\mathrm{O}$ inhame também é um alimento típico de Oxalá, mas de uma qualidade mais jovem, chamado Oxaguiã, que é um guerreiro cujas armas de ferro foram feitas por Ogun. Essa cerimônia é conhecida como festa do Pilão de Oxaguiãa, realizada dentro do ciclo de festividades para Oxalá.

\section{AnÁlise dos dAdos}

Olhar para o que se oferece hoje aos orixás nos contextos dos terreiros de candomblés e tentar responder ou explicar como aquela configuração de ingredientes, modos de fazer e formas de oferecimento se constituíram é certamente um desafio muito grande, senão impossível, tendo em vista o tempo decorrido, a complexidade dos fenômenos históricos imbricados, os poucos estudos publicados sobre a temática e, ainda, a existência de grandes lacunas documentais para o estudo desse problema. Contudo, não deixa de ser uma questão empolgante e necessária, sobre a qual vale a pena pensar, ou continuaremos apenas descrevendo e classificando comidas, em vez de

\footnotetext{
38 Verger 1997.

39 Lima 2010: 33-34.
} 
tentar compreender a dinâmica cultural e social do candomblé por meio da alimentação.

Analisando os pratos dos orixás e seus ingredientes, apresentados anteriormente, nota-se que quase todos são comestíveis e substanciosos, configurando uma dieta humana. Provavelmente teríamos dificuldade em ingerir a farofa de Exu encharcada de azeite de dendê e cachaça, ou os duros grãos tostados de Ogun e Oxóssi. Os demais pratos podem ser ingeridos e alguns são até bastante saborosos. Nos terreiros Ketu que estamos estudando, não se observam diferenças significativas entre as comidas que são ofertadas aos deuses e as que são consumidas pelos devotos. $\mathrm{O}$ que se observa nitidamente é a reafirmação das hierarquias pela diferença de quem come primeiro, que são sempre os orixás, seguidos pelos dirigentes e pessoas que possuem cargo e, por fim, pelas recém-iniciadas e os abians, aqueles que estão pretendendo se converter à religião. Há ocasiões em que se produzem comidas com ingredientes e formas de cocção não usuais, o que as inviabiliza para o consumo humano, sinalizando claramente que são apenas para as entidades espirituais. Mas, como dissemos anteriormente, na maioria das celebrações, o que sobra das preparações destinadas aos orixás geralmente é consumido pelos integrantes, principalmente os pratos mais desejados, como o acarajé e o amalá, que já são feitos em quantidade abundante para sobrar. Assim, temos que concordar com Vivaldo da Costa Lima quando rechaça a interpretação de que os pratos ofertados são comidas exclusivas das divindades. As comidas dos santos eram e continuam sendo também as comidas dos homens ${ }^{40}$.

Analisando qualitativamente a origem e a proveniência dos ingredientes mais comuns usados nos terreiros, observam-se, na culinária ritual, as interações e transformações sociais resultantes do advento das navegações que interconectaram o planeta. "O intercâmbio de produtos de diferentes continentes, que ocorreu no bojo da expansão colonial europeia, alterou radicalmente a dieta de praticamente todos os povos do mundo" ${ }^{41}$. Aqui não há espaço para a "pureza" que romanticamente buscava Manuel Querino. Encontramos muitos alimentos nativos da África, como o inhame, o quiabo, o obi, o orobô, a pimenta da costa e, principalmente, o dendê. Da América, destaca-se o milho, a mandioca, a pimenta vermelha e o tabaco, além de criações brasileiras como a cachaça e o aluá e, ainda, os animais da fauna regional. Dos insumos que foram trazidos da Europa, estão principalmente os feijões, a cebola, o azeite de oliva e os animais de corte; alguns poucos são provenientes do continente asiático, como o coco, o camarão seco e as pombas. Roger Bastide escreveu que os orixás, além de glutões, eram finos

\footnotetext{
40 Lima 2010: 18-19.

${ }^{41}$ Meneses e Carneiro 1997: 47.
} 
gourmets $^{42}$. Podemos acrescentar que, na Bahia, eles se tornaram apreciadores de uma boa cozinha internacional!

Mas a classificação exata das espécies vegetais e a verificação de sua origem é uma tarefa difícil da etnobotânica, mas que tem grande potencial para ser desenvolvida com relação aos terreiros de candomblét ${ }^{3}$. Como as plantas estão no planeta há milhões de anos, os complexos fenômenos de dispersão e especiação geraram muitos vegetais aparentados mundo afora. Muitas plantas africanas possuem similares na flora brasileira, como, por exemplo: as bananas, frequentes nos dois lados; as mancarras africanas, que se assemelham ao nosso amendoim; os milhetos, bem menores e menos suculentos que o nosso milho; e o sorgo, cuja farinha tem semelhança, nas formas de uso, com a farinha de mandioca. Até o dendezeiro tem uma palmeira aparentada na floresta amazônica ${ }^{44}$. A situação ficou ainda mais complexa quando a travessia atlântica se consolidou, pois, com o passar do tempo, houve permutas entre os vegetais e animais de cada margem. "Duzentos anos depois, os africanos ocidentais não compreendiam como o milho, o amendoim, a mandioca, a pimenta, fundamentais na sua alimentação, não fossem nativas como eles próprios" ${ }^{45}$. Por isso, muitas trocas alimentares para o culto aos orixás foram feitas, provavelmente, ainda no continente africano, pois, quando os iorubás começaram a ser trazidos em massa para a cidade de Salvador, entre o final do século XVIII e o começo do século XIX, muitos alimentos americanos já tinham se popularizado na África.

Segundo Roger Bastide, o que mais importava para os escravos não era a matéria de que era feita a comida, mas sim o nome que os fazia lembrar da terra de origem ${ }^{46}$. Ainda que a importância linguística não deva ser contestada, não podemos concordar com essa afirmação, pois, analisando a presença de cada elemento nos pratos relatados anteriormente, é possível observar uma intencionalidade, mesmo que coletiva e inconsciente, na escolha e uso dos ingredientes. Em primeiro lugar, nota-se uma nítida dominância do milho branco, representado pelo acaçá, que, como já foi dito, é a mais usual comida de terreiro e pode ser ofertada como acompanhamento para qualquer orixá. Simbolicamente, esse alimento define o primeiro lugar na hierarquia de importância dos orixás, que é de Oxalá, o pai de todos. O milho branco cozido ainda entra como constituinte das comidas de Iemanjá e Nanã, que, segundo os mitos, foram suas esposas. A imposição da autoridade desse orixá também

\footnotetext{
42 Bastide 2011: 175-176.

43 Camargo 1990.

44 Camargo 1990: 88.

45 Cascudo 2004: 826.

46 Bastide 2011b: 191.
} 
é perceptível pela obrigatoriedade de seu animal favorito: "todo santo come pombo por causa de Oxalá", afirma Olga do Alaketu ${ }^{47}$.

A segunda dominância observada se refere ao azeite de dendê, símbolo de Exu, que só não é utilizado para Oxalá e para as qualidades funfun dos orixás, ou seja, para os orixás que se vestem de branco, como Ayrá, a qualidade mais velha de Xangô. $\mathrm{O}$ azeite de dendê, além de ser usado nas comidas, é untado nos assentamentos de todos os orixás "quentes".

O terceiro alimento dominante é o quiabo, adorado por Xangô, que o conecta ao caruru de Ibeji, que é seu filho, e também a comidas especiais (não descritas aqui) que são feitas para Iansã, a sua esposa preferida; para Oxumarê, o orixá do arco-íris que fertiliza o palácio de Xangô; e ainda para Onilé, a misteriosa mãe-terra iorubana, cultuada em poucos terreiros. Talvez a explicação para a perda do alimento original do amalá, que era o inhame, tenha ocorrido na linhagem Ketu que estamos estudando, justamente porque o quiabo se tornou o ícone de Xangô, enquanto o inhame se tornou o de Ogun, que em certa medida é o seu rival. O inhame também cria uma rede simbólica. Além de ser a insígnia de Ogun, está presente na comida de Oxaguiãn, para quem Ogun fez as armas, e no ipete de Oxum, que foi sua esposa. Observa-se também a recorrência dos milhos amarelos, que fazem a ligação entre os orixás da rua: axoxó para Ogun e Oxóssi e milho de pipoca para Omolu. E, finalmente, há a repetição do feijão fradinho, símbolo de Oxóssi, que está presente no omolokun de Oxum, sua esposa predileta, e também no acarajé de Iansã, que foi aprendiz de Oxóssi nas artes da caça e na habilidade de se transformar em búfalo.

Assim, vemos que os ingredientes não devem ser observados isoladamente, mas segundo suas redes de afinidades e oposições aos símbolos aos quais estão associados. Essa trama simbólica criada pelos ingredientes e alimentos se estende também às nações dos terreiros. É comum que uma comida considerada essencial em uma nação seja a quizila de outra. Por exemplo, em muitos terreiros Ketu, Iemanjá come carneiro, enquanto que, em outros, o carneiro é o seu tabu. Portanto, ao contrário de aleatórios ou irrelevantes, os ingredientes usados nos pratos indicam que há uma "gramática" subjacente à culinária ritual dos terreiros.

Embora tenhamos abordado pratos para os orixás cujo conhecimento é partilhado entre terreiros de matriz Ketu e seus descendentes, não significa que todas as suas práticas sejam homogêneas. E a alimentação é um campo da ação humana que deixa isso bem visível. As comidas dos orixás expressam diversos níveis de identidade nos pratos, desde o mais geral até o mais específico: a) por um lado, são oferendas que expressam cosmologias e costumes

${ }^{47}$ Régis 2010: 105. 
arraigados nas estruturas mentais dos integrantes dessas comunidades. São práticas altamente difundidas entre todos os tipos de terreiros de candomblé do Brasil, indicando assim uma identidade que atravessa fronteiras culturais e geográficas em nível nacional; b) alguns pratos, como os das entidades Exu, Ogun, Iansã e Oxalá, são montados com ingredientes bem conhecidos e reconhecidos pelos diversos e distintos terreiros da Bahia, constituindo práticas comuns entre terreiros de diferentes linhagens ou nações. Nesse sentido, esses pratos expressam identidade em nível regional; c) por outro lado, existem pratos que são feitos em terreiros específicos, que notoriamente são fruto de um saber especial ou herança cultural sobre determinados ritos e comidas. Nesse nível, os pratos dos orixás expressam personalidade familiar, própria do terreiro ou da família espiritual. São exemplos o boi de Oxóssi da Casa Branca, as comidas para as Iyamis no Terreiro do Gantois e as comidas para os Eguns no Ilê Axé Opo Aganju. Ainda é possível identificar nos pratos até mesmo preferências ou determinações pessoais, pois as cozinheiras, os sacerdotes e as sacerdotisas dos terreiros também podem manifestar sua vontade por meio da alimentação. Não devemos esquecer a ativa atuação de importantes Iyalorixás, como Marcelina da Casa Branca, Mãe Aninha e Mãe Senhora do Ilê Axé Opô Afonjá, que se destacaram como mães de santo, sendo reconhecidas até mesmo na África. Provavelmente elas deixaram suas marcas nas comidas dos terreiros.

\section{Considerações finais}

Entendendo os pratos servidos aos orixás como complexos artefatos, advogamos a pertinência da visão arqueológica para o estudo da alimentação ritual nos terreiros de candomblé, de modo a analisar a cultura material a partir da forma, do espaço e do tempo. Por enquanto, o que aqui apresentamos foi uma "arqueologia" bibliográfica nas obras clássicas sobre as comidas dos orixás que continuam sendo oferecidas em uma linhagem de terreiros Ketu da Bahia, onde fazemos pesquisas etnoarqueológicas. O confronto das informações bibliográficas com as observações participantes e as informações orais evidenciaram muitas continuidades, mas também ficaram evidentes as mudanças e transformações dos pratos ao longo do tempo.

Refutando a ideia de que os ingredientes dos pratos dos orixás tinham pouca importância na reconstrução de suas comidas preferidas, indicamos a predominância de seis ingredientes (milho branco, azeite de dendê, quiabo, inhame, milho amarelo e feijão fradinho), que na Bahia tornaram-se ícones dos orixás mais celebrados pela nação Ketu. O milho branco, matéria-prima usada em diversos rituais e comidas, muitas vezes na forma do acaçá, integra a maior rede de relações simbólicas com os outros ingredientes e pratos. Embora esteja associado aos orixás "frios", todas as divindades comem milho 
branco, pois o acaçá é um complemento universal na culinária dos terreiros. A presença inconteste do milho branco é o símbolo da primazia de Oxalá perante os outros orixás, pois, segundo os mitos, é o pai de todos eles e o criador do ser humano. A segunda maior predominância foi o azeite de dendê, associado às comidas "quentes", que são as preferidas por Exu. Esse orixá também tem uma posição hierárquica muito alta no panteão dos terreiros porque é o mensageiro dos orixás e está associado à dinâmica e à evolução do mundo: sem as suas oferendas nada acontece. Outra predominância é o uso de ingredientes associados a Ogun, o deus ferreiro da guerra, abridor de caminhos e solucionador dos conflitos humanos. Enquanto os milhos amarelos ligam Ogun com os outros orixás da rua, o inhame o liga ao seu pai e à sua esposa. Ainda notamos a rede de ligações simbólicas feita pelo quiabo, ícone de Xangô, o deus dos trovões, e o feijão fradinho, comida predileta de Oxóssi, o caçador. Apesar de esses dois orixás não terem papéis tão relevantes na cosmologia iorubá original, são historicamente importantes na Bahia, pois suas terras africanas mitológicas foram os locais de onde os fundadores dos antigos terreiros baianos vieram, como Oyó e Ketu. Por essa razão, esses dois orixás se tornaram os patronos da Casa Branca e do Ilê Axé Opô Afonjá.

Assim, nota-se uma intencionalidade, que pode atuar também de forma coletiva e inconsciente, na escolha e uso dos ingredientes nos pratos dos orixás, que, interpretados dentro de uma trama simbólica de afinidades e oposições, enunciam uma "gramática" subjacente à culinária ritual dos terreiros.

Concluindo, gostaríamos de salientar que nosso interesse pelas comidas dos orixás se deve ao fato de estarmos analisando sítios usados pelas comunidades de terreiros de candomblé para o oferecimento de presentes e também para o descarte de artefatos rituais. O dique do Tororó, por exemplo, uma lagoa natural que atualmente está no centro de Salvador, é um local centenário onde os terreiros mais antigos de Salvador fazem oferendas para Oxum e também onde despacham, ou seja, descartam a cultura material ritual usada nos cultos. Estamos procedendo ao levantamento superficial e o monitoramento de alguns locais, como bosques, pedreiras, lagoas, rios e praias, documentando as oferendas, principalmente os vestígios macroscópicos de seus alimentos constituintes. Partimos do pressuposto de que nos meios subaquáticos há maior probabilidade das oferendas formarem depósitos devocionais, pois, apesar de os alimentos serem facilmente degradados, é possível que restos orgânicos sejam preservados em meio úmido, onde a deterioração dos materiais é geralmente mais lenta. Nos locais em que forem detectados depósitos devocionais usados por longos períodos, será possível estudar a relação das formas das oferendas com o espaço e com a variação ao longo do tempo, confrontando-se a aparente ortodoxia das receitas e dos ritos com o que de fato, materialmente, foi oferecido aos orixás. 


\section{Agradecimentos}

Gostaríamos de agradecer as informações orais do Mogbá de Xangô e Ogan de Oxum, Sr. Antonio Luiz Santos Figueiredo, do terreiro Ilê Axé Iyá Nassô Oká, Casa Branca, e das diversas histórias e informações orais contadas pelo babalorixá do Ilê Axé Opô Oyá Igbale, Sr. Jairo José de Oliveira Barros Junior. Agradecemos também a Liliana Rotta, pesquisadora da alimentação, pela indicação e acesso a grande parte da bibliografia usada nesse trabalho.

\section{REFERENCIAS}

Araújo, E. (2011), Textos de negros e sobre negros, Imprensa Oficial do Estado de São Paulo; Museu Afrobrasil, São Paulo.

Bastide, R. (2011a), "A Cozinha dos Deuses (Alimentação e Candomblés)”, in E. Araújo (org.), Textos de negros e sobre negros, Imprensa Oficial do Estado de São Paulo, Museu Afrobrasil, São Paulo.

Bastide, R. (2011b), “Cozinha africana e cozinha baiana”, in E. Araújo (org.), Textos de negros e sobre negros, Imprensa Oficial do Estado de São Paulo, Museu Afrobrasil, São Paulo.

Camargo, M. T. L. A. (1990), "As plantas condimentícias nas comidas rituais de cultos afro-brasileiros", Revista do Instituto de Estudos Brasileiros 31: 81-94.

Carneiro, É. (8. a ed., 1991), Candomblés da Bahia, Civilização Brasileira, Rio de Janeiro.

Cascudo, L. C. (4. ${ }^{a}$ ed., 2002), Made in Africa, Global, São Paulo.

Cascudo, L. C. (2004), História da Alimentação no Brasil, Global, São Paulo.

Cunha, M. C. (1983), "Arte Afro-Brasileira", in W. Zanini (coord.), História Geral da Arte no Brasil, vol. II, Instituto Walther Moreira Salles, São Paulo, 973-1033.

Douglas, M. (2011), In the active voice, Routledge \& Kegan Paul, Londres.

Flandrin,J.L.,Montanari, M. (4. ${ }^{a}$ ed., 1998), História da Alimentação, Estação Liberdade, São Paulo.

Hodder, I. (1982), Symbols in Action: Ethnoarchaeological Studies in Material Culture, Cambridge Univesity Press, Cambridge.

Iphan (2007), Ofício das Baianas de Acarajé: Dossiê Iphan 6, Iphan, Brasília.

Joannès, F. (4. a ed., 1998), "A função social do banquete nas primeiras civilizações", in J. L. Flandrin, M. Montanari, História da Alimentação, Estação Liberdade, São Paulo, 54-67.

Lima, V. C. (2010), "Introdução" e "Notas", in O. F. Régis, A comida de Santo numa casa de Queto da Bahia, Corrupio, Salvador.

Lody, R. (1979), Santo também come, Instituto Joaquim Nabuco de Pesquisas Sociais, Recife.

Lody, R. (1992), Tem dendê tem axé: etnografia do dendezeiro, Pallas, Rio de Janeiro. 
Lody, R. (1998), “O rei come quiabo e a rainha come fogo”, in C. E. M. de Moura (org.), Leopardos dos olhos de fogo: Escritos sobre a religião dos Orixás, Ateliê Editorial, São Paulo.

Meneses, U. T. B., Carneiro, H. (1997), "A História da Alimentação: balizas historiográficas", Anais do Museu Paulista 5: 9-91.

Mariano, A., Queiroz, A., Jaques, D. et al. (2009), Obarày: Babalorixá Balbino Daniel de Paula, Barabô, Salvador.

Querino, M. (3. ${ }^{\mathrm{a}}$ ed., 2011), A arte culinária na Babia, Editora WMF Martins Fontes, São Paulo.

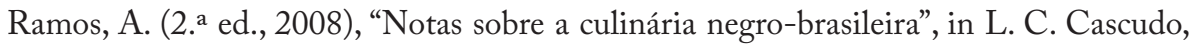
Antologia da alimentação no Brasil, Global, São Paulo.

Régis, O. F. (Olga do Alaketu) (2010), A comida de Santo numa casa de Queto da Bahia, Corrupio, Salvador.

Rodrigues, R. N. (2006), O animismo fetichista dos negros baianos, Fundação Biblioteca, Rio de Janeiro, Fundação Biblioteca Nacional/Ed. UFRJ.

Rodrigues, R. N. (2008), Os africanos no Brasil, Madras, São Paulo; Rio de Janeiro, Fundação Biblioteca Nacional/Editora UFRJ.

Santos, E. A. (Mãe Aninha) (1940), "Notas sobre Comestíveis Africanos", in Atas do II Congresso Afro-Brasileiro (Bahia, 1937), Civilização Brasileira, Rio de Janeiro.

Soares, R. O. (2005), Feitiço de Oxum: um estudo sobre o Ilê Axé Iyá Nassô Oká e suas relações em rede com outros terreiros, Tese de doutorado em Ciências Sociais, UFBA, Salvador.

Souza Jr., V. C. (2009), O banquete sagrado: notas sobre os "de comer" em terreiros de candomblé, Atalho, Salvador.

Teles, J. (2009), Os candomblés no século XXI, Centro de Estudos Afro-Orientais da UFBA, Salvador.

Verger, P. (1981), Orixás: deuses iorubás na África e no Novo Mundo, Corrupio, São Paulo.

Verger, P. (1992), "Esplendor e decadência do culto de Iyami Osoronga entre os iorubas: Minha Mãe Feiticeira”, in P. Verger, Artigos, Tomo I, Corrupio, São Paulo, 5-91.

Verger, Pierre Fatumbi (1997), Lendas africanas dos Orixás. [ilustrações] Carybé; tradução Maria Aparecida da Nóbrega, 4. ed., Salvador, Corrupio. 